Jurnal At-Tibyan: Jurnal Ilmu Alqur'an dan Tafsir

Volume 5 No. 1, Juni 2020 (h.57-73)

P ISSN 2442-594X | E ISSN 2579-5708

http://journal.iainlangsa.ac.id/index.php/tibyan

\title{
KAIDAH PENAFSIRAN AL-QUR'AN DAN URGENSINYA DI ERA DISRUPSI
}

\author{
The Rules Of The Qur'anic's Interpretation And Their Urgension In \\ The Disruption Era
}

Arham Junaidi Firman

UIN Sunan Kalijaga Yogyakarta, Indonesia

arhamjf@yahoo.com

\begin{tabular}{|l|l|l|}
\hline \multicolumn{2}{|c|}{ DOI: 10.32505/tibyan.v5i1.1393 } \\
\hline Submitted: 02-01-2020 & Revised: 22-06-2020 & Accepted: 26-06-2020 \\
\hline
\end{tabular}

\begin{abstract}
The study of interpretation in the disruption era is done to avoid the error of interpretation so that it does not correspond to the intent of the content of the Qur'an. This is because the Qur'an as the miracle of the Prophet Muhammad saw. contains extraordinary beauty and greatness as a guideline for human beings. The rule of interpretation of the Qur'an in the disruption era is a decree that helps an interpreter or exegetes to withdraw the meaning/messages of the Qur'an and explain what is a misconception of the verses content in relation to the increasingly unexpected changes. The rules of the Qur'anic exilence can be used as guidelines in this disruption era can refer to the view of Abd ar-Rahman ibn Nasir Al-Sa'adi in his books AlQawaid Al-Hisan Al-Qur'anic Tafsir as quoted by Abd. Rahman Dahlan that there are five rules of the Qur'an interpretation. Meanwhile, Muhammad Chirzin in his book presents twelve rules of interpretation of the Qur'an that can be used as a guideline in the disruption era. Meanwhile, the importance of the interpretation of the Qur'an in the disruption era, namely; First, it can help a person's interpreter in revealing the expressed or implied meaning in the Qur'an, so that it can do it reveal what if it is still vague and unclear. Secondly, in order not to give the etymological meaning of the pronunciation of the Qur'an with other meanings that are not appropriate, both in the meaning of the essence and the meaning of majazi.
\end{abstract}

Keywords: The Rules of Interpretation, Al-Qur'an, Disruption Era

Hak Cipta @ 2020. Dimiliki oleh Penulis, dipublikasikan oleh Jurnal At-Tibyan: Jurnal Ilmu Alqur'an dan Tafsir.

Artikel dengan akses terbuka. Lisensi: CC-BY

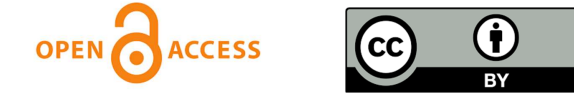




\begin{abstract}
Abstrak
Kajian kaidah penafsiran di era disrupsi ini dilakukan untuk menghindari terjadinya kesalahan penafsiran sehingga tidak sesuai dengan maksud dari kandungan Al-Qur'an. Hal ini dikarenakan Al-Qur'an sebagai mukjizat Nabi Muhammad saw. mengandung keindahan dan kehebatan yang sangat luar biasa sebagai pedoman bagi manusia. Kaidah penafsiran Al-Qur'an di era disrupsi merupakan ketetapan-ketetapan yang membantu seorang penafsir atau mufassir untuk menarik makna/pesan-pesan Al-Qur'an dan menjelaskan apa yang musykil dari kandungan ayat-ayatnya dalam kaitannya dengan perubahan yang semakin tidak terduga. Kaidah-kaidah dalam menfasirkan Al-Qur'an yang bisa dijadikan pedoman di era disrupsi ini dapat merujuk kepada pandangan Abd ar-Rahman ibn Nasir al-Sa'adi dalam kitabnya $A 1-$ Qawaid Al-Hisan li Tafsir Al-Qur'an sebagaimana yang dikutip oleh Abd. Rahman Dahlan bahwa ada lima kaidah penafsiran Al-Qur'an. Sedangkan, Muhammad Chirzin dalam bukunya mengemukakan dua belas kaidah penafsiran Al-Qur'an yang bisa dijadikan pedoman di era disrupsi. Sementara itu, urgensi kaidah penafsiran Al-Qur'an di era disrupsi, yaitu; pertama, dapat membantu seseorang penafsir dalam mengungkap makna yang tersurat atau bahkan tersirat di dalam Al-Qur'an, sehingga dapat mengantarnya mengungkap apa yang sekiranya masih samar dan belum jelas. Kedua, agar tidak memberikan arti etimologis suatu lafadh Al-Qur'an dengan arti lain yang tidak sesuai, baik dalam arti hakiki maupun arti majazi.
\end{abstract}

\title{
Kata Kunci: Kaidah Penafsiran, Al-Qur'an, Era Disrupsi
}

\section{Pendahuluan}

Al-Qur'an sebagai mukjizat Nabi Muhammad saw. merupakan kalam Allah swt. yang tiba kepada masyarakat muslim dengan metode al-tawatur (langsung dari Rasul kepada umatnya) serta kemudian tercantum dalam mushaf. Pada awal abad ke-7, pesan Ilahi yang disampaikan oleh Nabi saw. itu memiliki kandungan yang bersifat holistik (menyeluruh), baik itu tentang akidah, fiqh, akhlak dan lainnya sehingga menjadi dasar bagi kehidupan individual dan bersosial bagi umat Islam dalam segala lingkupnya. ${ }^{1}$

Al-Qur'an sebagai pedoman bagi manusia memiliki kehebatan dan keindahan yang sangat luar biasa. Memiliki keindahan karena disusun dalam bahasa yang sangat indah dan memiliki kandungan sastra yang begitu tinggi, sehingga tidak ada orang yang mampu menandingi kehebatannya. Al-Qur'an berposisi tepat di jantung umat muslim dalam berbagai pengalaman keagamaan dan kepercayaannya. Tanpa mempunyai pemahaman yang semestinya terhadap Al-Qur'an, tentunya kehidupan, pemikiran dan kebudayaan muslim akan sulit dipahami, terkadang terdapat masalah-

\footnotetext{
${ }^{1}$ Tim Mahasiswa Pasca Sarjana PAI UIN Sunan Kalijaga A2 '17, Studi Al-Qur'an: Teori dan Aplikasinya dalam Penafsiran Ayat Pendidikan (Yogyakarta: Diandra Kreatif, 2018), 127.
} 
masalah yang belum begitu jelas sehingga dibutuhkan penafsiran terhadap Al-Qur'an tersebut.

Penafsiran Al-Qur'an sebagai wahyu yang diturunkan Allah swt. ke dalam hati Rasulullah saw. sudah di mulai pada masanya sebagai manusia pertama yang menguraikan dan menjelaskan kepada umatnya. Penjelasan Rasulullah itu terkadang melalui sunnah qauliyah, sunnah fi'liyah dan sunnah taqririyah. ${ }^{2}$ Rasulullah adalah guru pertama yang mengajarkan Al-Qur'an dengan cara menjelaskan maksud dan menguraikan ungkapan-ungkapannya yang sulit. ${ }^{3}$ Allah swt. berfirman dalam Q.S. AnNahl ayat 44 yang berbunyi:

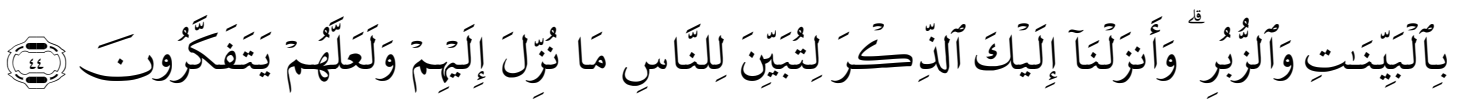

Artinya: "Keterangan-keterangan (mukjizat) dan kitab-kitab. dan Kami turunkan kepadamu Al-Qur'an, agar kamu menerangkan pada umat manusia apa yang telah diturunkan kepada mereka dan supaya mereka memikirkan" (Q.S. AnNahl [16 ]: 44). ${ }^{4}$

Allah swt. juga berfirman dalam Q.S. Al-Jumu'ah ayat 2 yang berbunyi:

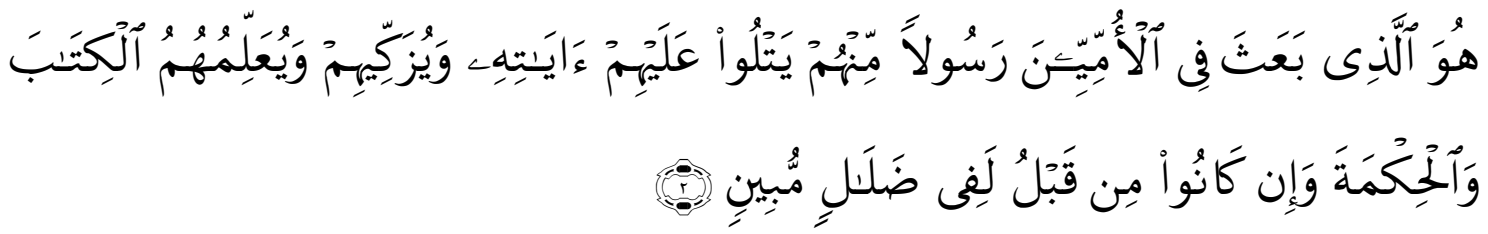

Artinya: Dia-lah yang mengutus kepada kaum yang buta huruf seorang Rasul di antara mereka, yang membacakan ayat-ayat-Nya kepada mereka, mensucikan mereka dan mengajarkan mereka kitab dan Hikmah (As Sunnah). dan Sesungguhnya mereka sebelumnya benar-benar dalam kesesatan yang nyata”. (Q.S. Al-Jumu'ah [62 ]: 2). ${ }^{5}$

Pada masa nabi Muhammad saw., sekelompok sahabat atas perintahnya membaca Al-Qur'an, menghapalkan dan mendalaminya sehingga mendapat gelar sebagai Al-Qurra'.6 Setelah Nabi Muhammad saw. berpulang ke rahmatullah, maka para sahabat dengan inisiatif sendiri tampil ambil bagian karena terpanggil untuk menjelaskan dan menerangkan apa saja yang diketahui dan dipahami tentang AlQur'an. Ahli tafsir di kalangan para sahabat Nabi banyak jumlahnya, tapi yang terkenal luas hanya 10 orang, yaitu: Abu Bakar ash-Shiddik, Umar bin Khattab, Utsman bin Affan, Ali bin Abi Thalib, Abdullah bin Mas'ud, Ibnu Abbas, Ubay bin Ka'ab, Zaid bin Tsabit, Abu Musa al-Asy'ari dan Abdullah bin Zubair. Setelah nabi Muhammad saw.

\footnotetext{
${ }^{2}$ Muhammad Hasbi Ash Shiddieqy, Sejarah dan Pengantar Ilmu Al-Qur'an/Tafsir (Jakarta: Bulan Bintang, 1992), 205.

${ }^{3}$ Allamah M.H. Thabathaba'i, Mengungkap Rahasia Al-Qur'an, (Bandung: Mizan, 1994), 63.

${ }^{4}$ Departemen Agama RI, Al-Hikmah; Al-Qur'an dan Terjemahannya, (Bandung: Diponegoro, 2008), 272

${ }^{5}$ Departemen Agama RI, Al-Hikmah; Al-Qur'an dan Terjemahannya, 553.

${ }^{6}$ Allamah M.H. Thabathaba'i, Mengungkap, 64.
} 
dan sahabat-sahabatnya wafat, kaum muslimin terus menerus menafsirkan Al-Qur'an sampai sekarang. ${ }^{7}$

Dalam perkembangannya, ilmu tafsir secara umum menurut pandangan Islam merupakan ilmu yang paling mulia dan paling baik. Hal ini dapat diketahui dan dipahami melalui perintah Allah swt. untuk memikirkan dan merenungi makna-makna yang terkandung dalam Al-Qur'an, serta menjadikannya sebagai petunjuk keselamatan dan kebahagiaan di dunia-akhirat. Akan tetapi, dalam beberapa tahun terakhir sering didengar, ditemui dan dilihat penafsiran Al-Qur'an dilakukan berdasarkan subjektivitas penafsir tanpa memperhatikan kaidah-kaidah penafsiran. Misalnya; kesalahan tafsir Surah Yasin ayat 13-14 dalam Al-Quran "Miracle The Reference" pada tahun 2012 terbitan PT Sygma Examedia Arkanleema, ${ }^{8}$ kontroversi atas kasus dugaan penistaan agama yang dilakukan oleh Gubernur DKI Jakarta Basuki Tjahaja Purnama (Ahok), yaitu salah tafsir Al-Qur'an surah Al Maidah ayat 51 pada kata awliya yang memiliki arti sebagai pemimpin atau wali, berubah menjadi teman setia. ${ }^{9}$

Analisis terhadap permasalahan-permasalahan di atas, maka untuk menghindari terjadinya kesalahan dan penafsiran yang tidak sesuai dengan apa yang terkandung dalam Al-Qur'an, maka seorang mufassir harus mengetahui kaidah-kaidah penafsiran sebagai pedoman dalam menafsirkan Al-Qur'an. Oleh karena itu, kajian ini mengungkap lebih dalam bagaimana kaidah-kaidah penafsiran yang pada tahap akhir dapat digunakan sebagai pedoman dalam menafsirkan Al-Qur'an. Berdasarkan hal tersebut, maka hal menarik untuk dikaji lebih lanjut, yaitu bagaimana kaidah penafsiran Al-Qur'an dan urgensinya di era disrupsi.

\section{Memahami Kaidah dalam Menfasirkan Al-Qur'an di Era Disrupsi}

Era disrupsi merupakan waktu ketika perubahan terjadi sedemikian tidak terduga, mendasar dan hampir dalam semua aspek kehidupan. Disrupsi menginisiasi lahirnya model interaksi baru yang lebih inovatif dan masif mulai dari dunia usaha, perbankan, transportasi, sosial kemasyarakatan, pendidikan hingga politik. ${ }^{10}$ Apabila istilah disrupsi ini dikaitkan dengan tafsir, maka memiliki arti bagaimana upaya menafsirkan ayat-ayat Al-Qur'an diadaptasikan dan disesuaikan dengan suasana dan kondisi pada saat ini yang sedang dipengaruhi dan berada dalam suasana kehidupan serba tidak jelas. Pada era disrupsi ini sangat penting bagi semua pihak untuk memahami Al-Qur'an secara komprehensif, karena akan membawa dampak bagi kehidupan dunia dan akhirat. Pemahaman Al-Qur'an yang tidak komprehensif akan menyebabkan salah dalam memahami makna yang terkandung di dalam Al-Qur'an. Sejak masa sahabat hingga saat ini, semakin marak kejadian salah tafsir Al-Qur'an

\footnotetext{
${ }^{7}$ Subhi as-Shalih, Membahas Ilmu-IImu Al-Qur'an (Jakarta: Pustaka Firdaus, 2011), 411.

${ }^{8}$ Hery H Winarno, "MUI: Musnahkan Al-Qur'an Miracle The Reference yang Salah Tafsir", (Online), diakses dari https://www.merdeka.com, pada tanggal 20 Desember 2019 pukul 08.56 WIB.

${ }^{9}$ Bayu Hermawan, "Netizen Dihebohkan dengan 'Berubahnya' Tafsir Al Maidah Ayat 51", (Online), diakses dari https://www.republika.co.id, pada tanggal 20 Desember 2019 pukul 09.00 WIB.

${ }^{10}$ Khoiruddin Bashori, "Pendidikan Politik di Era Disrupsi", dalam Sukma: Jurnal Pendidikan 2 , no. 2 (2018): 287-310
} 
sebagai pemaparan penulis pada bagian pendahuluan yang berdampak terhadap kemaslahatan umat, sehingga diperlukan pengetahuan, pemahaman dan penerapan untuk menafsirkannya.

Kaidah penafsiran atau dalam bahasa Arab dikenal dengan istilah Qawaid AlTafsir adalah kata jamak yang terdiri dari kata qawaid dan tafsir. Qawaid sebagai jamak dari kata qai'dah atau kaidah dalam bahasa Indonesia dapat dipahami sebagai pengertian secara etimologis. Kata qa'idah secara semantik, berarti asas, dasar, pedoman, atau prinsip. ${ }^{11}$ Dalam bahasa Arab kata qa'idah diartikan asas/fondasi jika dikaitkan dengan bangunan dan bermakna tiang jika dikaitkan dengan kemah. ${ }^{12}$

Sedangkan, tafsir secara etimologi mengikuti wazan taf'il dari kata Al-Fasr dengan arti menjelaskan dan mengungkapkan, menyingkap dan memperlihatkan atau menerangkan maksud yang abstrak. Menurut Abu Hayyan sebagaimana dikutip oleh Manna' Khalil Al-Qattan, tafsir merupakan ilmu yang membicarakan tentang metode mengungkapkan kata-kata Al-Qur'an, petunjuk-petunjuknya, hukum-hukumnya, meski ketika berdiri dengan sendirinya atau tersusun dan maksud-maksud yang dimungkinkannya ketika dalam keadaan tersusun serta hal-hal yang melengkapinya. ${ }^{13}$

Dari hal di atas, dapat dipahami kaidah penafsiran Al-Qur'an pada era disrupsi merupakan ketetapan-ketetapan yang membantu seorang penafsir atau mufassir untuk menarik makna/pesan-pesan Al-Qur'an dan menjelaskan apa yang musykil dari kandungan ayat-ayatnya dalam kaitannya dengan perubahan yang semakin tidak terduga. Selain itu, dalam hemat penulis sebagai seorang praktisi pendidikan melihat bahwa kaidah penafsiran ini sebagai kurikulum yang memainkan peranan penting dalam dunia pendidikan, karena merupakan alat untuk mencapai tujuan yang dicitacitakan.

Sementara itu, kaidah-kaidah dalam menfasirkan Al-Qur'an yang bisa dijadikan pedoman di era disrupsi ini dapat merujuk kepada pandangan Abd ar-Rahman ibn Nasir al-Sa'adi dalam kitabnya Al-Qawaid Al-Hisan li Tafsir Al-Qur'an sebagaimana yang dikutip oleh Abd. Rahman Dahlan, yaitu: Pertama, kaidah yang terkait dengan kebahasaan. Kedua, kaidah yang terkait dengan hukum. Ketiga, kaidah yang berhubungan dengan ilmu Al-Qur'an. Keempat, kaidah yang berhubungan dengan tauhid. Kelima, kaidah yang berkaitan dengan pedoman hidup. ${ }^{14}$ Sedangkan, Muhammad Chirzin dalam bukunya sebagaimana yang dipaparkan pada tulisan ini dalam hemat penulis menunjukkan bahwa ada dua belas kaidah yang harus diperhatikan oleh seorang mufassir dalam menafsirkan Al-Qur'an, yaitu: ${ }^{15}$

\footnotetext{
${ }^{11}$ Supiana-M. Paman, Ulumul Qur'an (Bandung: Pustaka Islamika, 2002), 273.

${ }^{12}$ M. Quraish Shihab, Kaidah Tafsir, Syarat, Ketentuan dan Aturan yang Patut Anda Ketahui dalam Memahami Ayat-Ayat Al-Qur'an (Tangerang: Lentera Hati, 2013), 6.

${ }^{13}$ Manna' Khalil Al-Qattan, Studi Ilmu-Ilmu Al-Qur'an (Bogor: Pustaka Lintera Antar Nusa, 1994), 456.

${ }^{14}$ Abd. Rahman Dahlan, Kaidah-Kaidah Penafsiran Al-Qur'an (Bandung: Mizan, 1997), 10-13.

${ }^{15}$ Muhammad Chirzin, Al-Qur'an dan Ulumul Quran (Jakarta: Dana Bhakti Prima Yasa, 1998), xiixiv.
} 
1. Kaidah Dasar Tafsir, meliputi tafsir Al-Qur'an dengan Al-Qur'an, Al-Qur'an dengan As-Sunnah, Al-Qur'an dengan Qaul Shahabah dan Tafsir Tabi'in.

2. Kaidah Isim Fi'il

Isim menunjukkan tetapnya keadaan dan kelangsungan. Sedangkan fi'il menunjukkan adanya hal yang baru dan terjadinya suatu perbuatan. Masing-masing kata tersebut mempunyai tempat tersendiri dan tidak bisa diganti satu dengan yang lain untuk tetap menghadirkan kesamaan makna. ${ }^{16}$ Contohnya, yaitu dalam Q.S. Al-Kahfi ayat 18 untuk kaidah isim dan Q.S. Asy-Syu'ara' ayat 78-82.

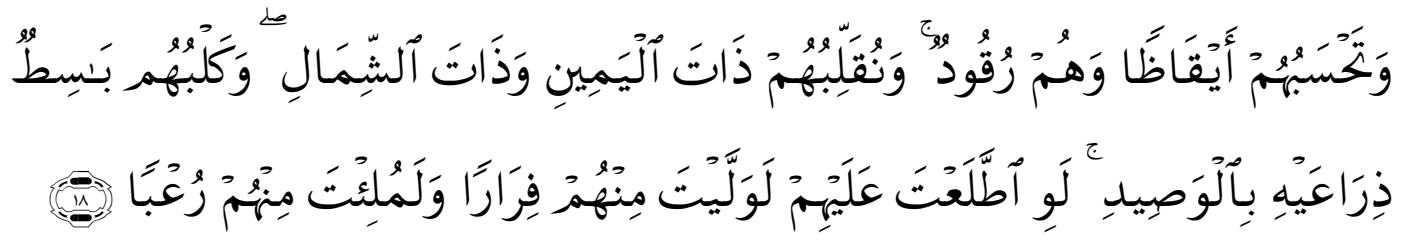

Artinya: "dan kamu mengira mereka itu bangun, Padahal mereka tidur; dan Kami balik-balikkan mereka ke kanan dan ke kiri, sedang anjing mereka mengunjurkan kedua lengannya di muka pintu gua. dan jika kamu menyaksikan mereka tentulah kamu akan berpaling dari mereka dengan melarikan diri dan tentulah (hati) kamu akan dipenuhi oleh ketakutan terhadap mereka". (Q.S. Al-Kahfi [18]: 18) ${ }^{17}$

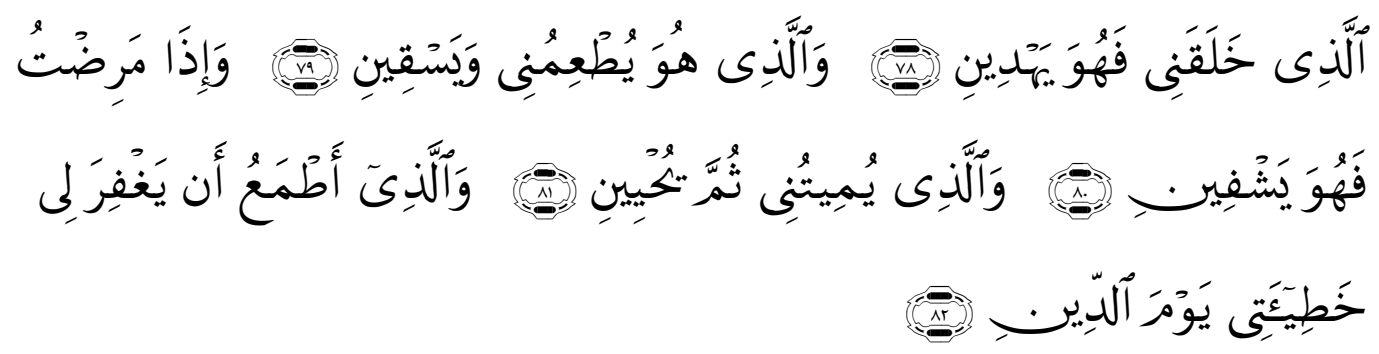

Artinya: "(Yaitu Tuhan) yang telah menciptakan Aku, Maka Dialah yang menunjuki Aku, dan Tuhanku, yang Dia memberi Makan dan minum kepadaKu, dan apabila aku sakit, Dialah yang menyembuhkan Aku dan yang akan mematikan Aku, kemudian akan menghidupkan aku (kembali), dan yang Amat kuinginkan akan mengampuni kesalahanku pada hari kiamat". (Q.S. Asy-Syu' ara' [26]: 78-82) ${ }^{18}$

3. Kaidah Amr dan Nahi

Secara bahasa amr berarti suruhan atau perintah. Secara istilah amr merupakan kata yang menunjukkan permintaan untuk mengerjakan apa yang diminta, dari arah yang lebih tinggi kedudukannya kepada kedudukan yang lebih rendah. ${ }^{19}$ Salah satu contohnya, yaitu dalam Q.S. An-Nisaa' ayat 77 yang berbunyi:

\footnotetext{
${ }^{16}$ Chirzin, Al-Qur'an dan Ulumul Quran, 157.

${ }^{17}$ Departemen Agama RI, Al-Hikmah; Al-Qur'an, 295.

${ }^{18}$ Departemen Agama RI, Al-Hikmah; Al-Qur'an, 370.

${ }^{19}$ Chirzin, Al-Qur'an, 165.
} 


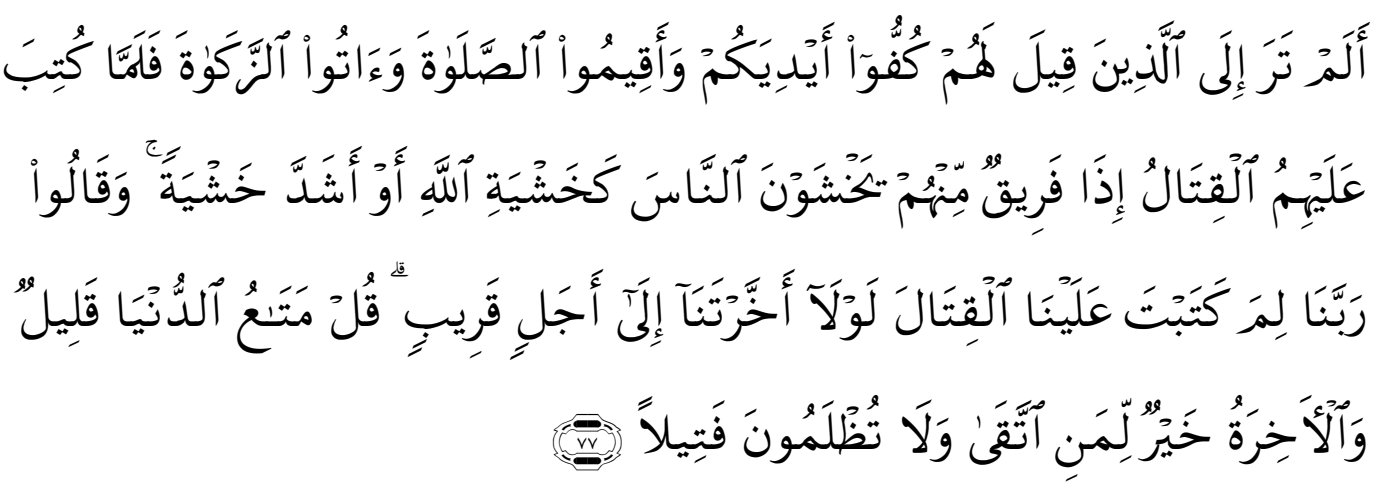

Artinya: "Tidakkah kamu perhatikan orang-orang yang dikatakan kepada mereka: "Tahanlah tanganmu (dari berperang), dirikanlah sembahyang dan tunaikanlah zakat!" setelah diwajibkan kepada mereka berperang, tibatiba sebahagian dari mereka (golongan munafik) takut kepada manusia (musuh), seperti takutnya kepada Allah, bahkan lebih sangat dari itu takutnya. mereka berkata: "Ya Tuhan Kami, mengapa Engkau wajibkan berperang kepada kami? mengapa tidak Engkau tangguhkan (kewajiban berperang) kepada Kami sampai kepada beberapa waktu lagi?" Katakanlah: "Kesenangan di dunia ini hanya sebentar dan akhirat itu lebih baik untuk orang-orang yang bertakwa, dan kamu tidak akan dianiaya sedikitpun". (Q.S. An-Nisaa' [4]:77). ${ }^{20}$

Sementara itu, nahi secara bahasa berarti larangan atau cegahan. Secara istilah nahi merupakan perkataan yang menunjukkan permintaan berhenti dari suatu perbuatan dari orang yang lebih tinggi kepada yang lebih rendah. Salah satu contohnya, yaitu dalam Q.S. Luqman ayat 13 yang berbunyi:

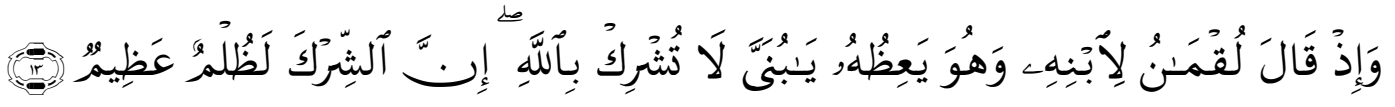

Artinya: "Dan (ingatlah) ketika Luqman berkata kepada anaknya, di waktu ia memberi pelajaran kepadanya: "Hai anakku, janganlah kamu mempersekutukan Allah, Sesungguhnya mempersekutukan (Allah) adalah benar-benar kezaliman yang besar". (Q.S. Luqman [31]:13). ${ }^{21}$

4. Kaidah Istifham

Istifham berasal dari Bahasa Arab merupakan masdar dari kata istafhama yang berarti istaudhaha. Asal katanya adalah fahima dengan arti paham, mengerti dan jelas. Asal kata ini mendapat penambahan huruf alif, sin dan ta' di awal kata dengan salah satu fungsinya untuk meminta. Dengan demikian ia berarti permintaan penjelasan (thalabul fahmi). ${ }^{22}$ Salah satu contohnya adalah dalam firman Allah Q.S. Al-Qiyamah ayat 6 yang berbunyi:

\footnotetext{
${ }^{20}$ Departemen Agama RI, Al-Hikmah; Al-Qur'an, 90.

${ }^{21}$ Departemen Agama RI, Al-Hikmah; Al-Qur'an, 412.

${ }^{22}$ Chirzin, Al-Qur'an, 177.
} 


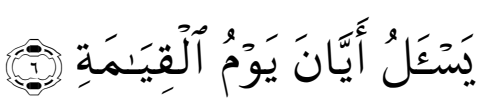

Artinya: Ia berkata: "Bilakah hari kiamat itu?” (Q.S. Al-Qiyamah [75]: 6). ${ }^{23}$

5. Kaidah Nakirah dan Ma'rifah

Isim nakirah merupakan kata beda tak tentu yang digunakan untuk menunjukkan isim tunggal, ragam atau macam, mengangungkan atau memuliakan, jumlah yang banyak, merendahkan, jumlah sedikit, tunggal dan macam sekaligus, mengangungkan dan menunjukkan banyak sekaligus serta menunjuk pengertian yang umum jika nakirah. ${ }^{24}$ Salah satu contohnya adalah dalam firman Allah Q.S. Al-Qasas ayat 20 yang berbunyi:

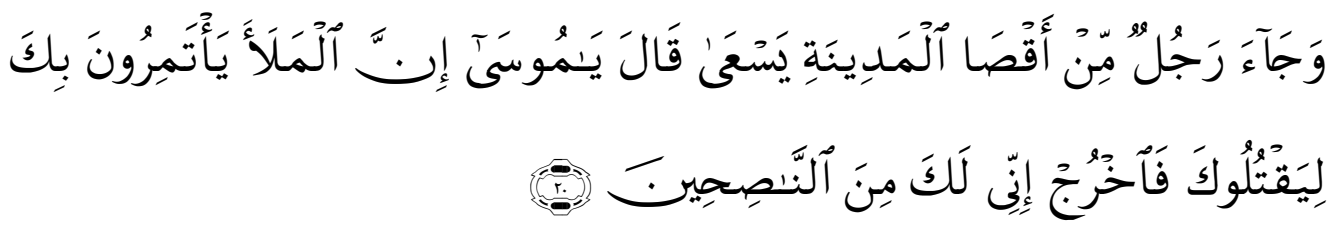

Artinya: "dan datanglah seorang laki-laki dari ujung kota bergegas-gegas seraya berkata: "Hai Musa, Sesungguhnya pembesar negeri sedang berunding tentang kamu untuk membunuhmu, sebab itu keluarlah (dari kota ini) Sesungguhnya aku Termasuk orang-orang yang memberi nasehat kepadamu". (Q.S. Al-Qasas [28]: 20). ${ }^{25}$

Sementara itu, isim ma'rifah merupakan kata benda tertentu yang terdiri dari beberapa macam dan digunakan sesuai macamnya, yaitu: Pertama, ta'rif dengan isim dhamir untuk meringkas kalimat. Kedua, ta'rif dengan 'alamiah untuk beberapa maksud seperti memuliakan atau mengungkap identitas. Ketiga, ta'rif dengan isim isyarah untuk maksud tertentu seperti menjelaskan keagungan yang ditunjuk dengan menggunakan kata tunjuk jauh. ${ }^{26}$ Salah satu contohnya adalah dalam firman Allah Q.S. Al-Baqarah ayat 2 yang berbunyi:

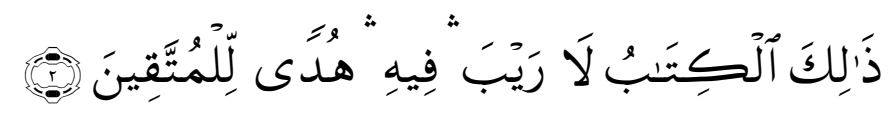

Artinya: "Kitab (Al Quran) ini tidak ada keraguan padanya; petunjuk bagi mereka yang bertaqwa". (Q.S. Al-Baqarah [2]: 2). ${ }^{27}$

6. Kaidah Mufrad dan Jamak

Mufrad merupakan sebutan untuk isim yang menunjukkan satu atau tunggal. Sementara itu jamak merupakan sebutan untuk menunjukkan sejumlah (banyak), baik manusia maupun makhluk lainnya. ${ }^{28}$ Diantara contohnya adalah

\footnotetext{
${ }^{23}$ Departemen Agama RI, Al-Hikmah; Al-Qur'an, 577.

${ }^{24}$ Chirzin, Al-Qur'an, 183.

${ }^{25}$ Departemen Agama RI, Al-Hikmah; Al-Qur'an, 387.

${ }^{26}$ Chirzin, Al-Qur'an, 186.

${ }^{27}$ Departemen Agama RI, Al-Hikmah; Al-Qur'an, 2.

${ }^{28}$ Chirzin, Al-Qur'an, 195.
} 
dalam firman Allah Q.S. Al-'Ankabut ayat 56 untuk mufrad dan Q.S. Al-Ghasiyyah ayat 13-14 yang berbunyi:

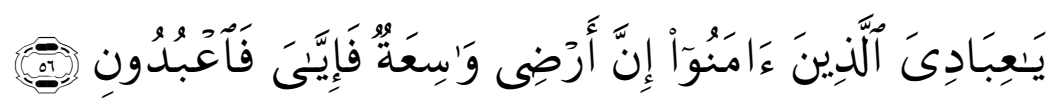

Artinya: "Hai hamba-hamba-Ku yang beriman, Sesungguhnya bumi-Ku luas, Maka sembahlah aku saja”. (Q.S. Al-'Ankabut[29]:56). ${ }^{29}$

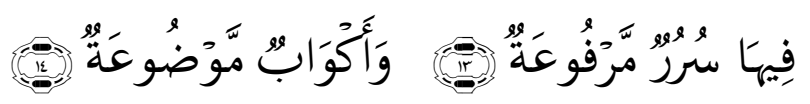

Artinya: "Di dalamnya ada takhta-takhta yang ditinggikan, dan gelas-gelas yang terletak (di dekatnya)". (Q.S. Al-Ghasiyyah [88]: 13-14). ${ }^{30}$

7. Kaidah Tanya Jawab

Lazimnya setiap pertanyaan membutuhkan jawaban yang sesuai dengan pertanyaannya, sehingga terpenuhilah apa yang menjadi keingintahuan penanya. ${ }^{31}$ Salah satu contohnya dapat dilihat pada firman Allah Q.S. Al-Baqarah ayat 189 yang berbunyi:

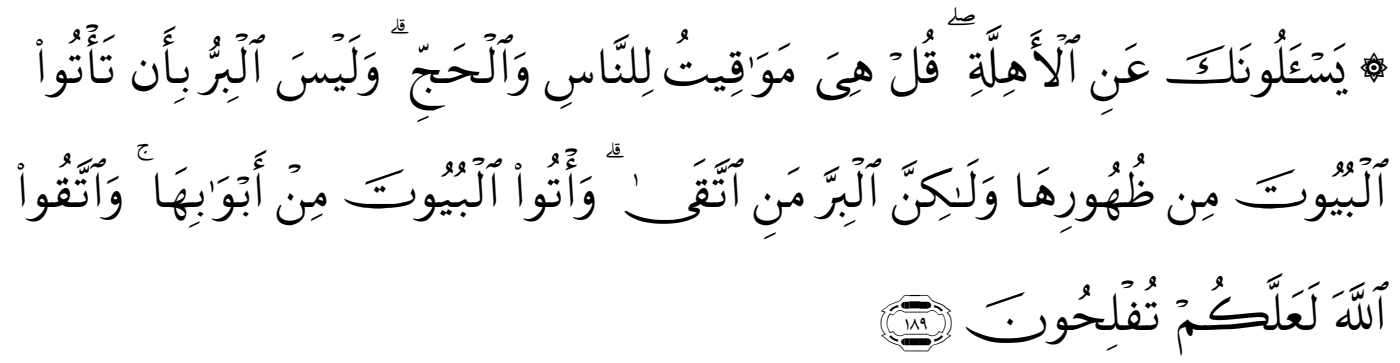

Artinya: "Mereka bertanya kepadamu tentang bulan sabit. Katakanlah: "Bulan sabit itu adalah tanda-tanda waktu bagi manusia dan (bagi ibadat) haji; dan bukanlah kebajikan memasuki rumah-rumah dari belakangnya, akan tetapi kebajikan itu ialah kebajikan orang yang bertakwa. dan masuklah ke rumah-rumah itu dari pintu-pintunya; dan bertakwalah kepada Allah agar kamu beruntung". (Q.S. Al-Baqarah [2]:189). ${ }^{32}$

8. Kaidah Wujuh dan Nazha'ir

Wujuh merupakan suatu lafadh yang memiliki makna ganda yang digunakan dalam beberapa maknanya yang beragam. Sedangkan nazha'ir ialah lafadh yang mempunyai suatu makna tertentu yang tetap sekalipun digunakan dalam berbagai tempat. Diantara contoh lafadh yang termasuk dalam kategori wujuh adalah alhuda dan lafadh yang termasuk dalam kategori nazha'ir adalah al-bahru. ${ }^{33}$ Allah

\footnotetext{
${ }^{29}$ Departemen Agama RI, Al-Hikmah; Al-Qur'an, 403.

${ }^{30}$ Departemen Agama RI, Al-Hikmah; Al-Qur'an, 592.

${ }^{31}$ Chirzin, Al-Qur'an, 201.

${ }^{32}$ Departemen Agama RI, Al-Hikmah; Al-Qur'an, 29.

${ }^{33}$ Chirzin, Al-Qur'an, 207.
} 
swt. berfirman dalam Q.S. Al-Baqarah ayat 38 dan Q.S. Al-An'am ayat 59 yang berbunyi:

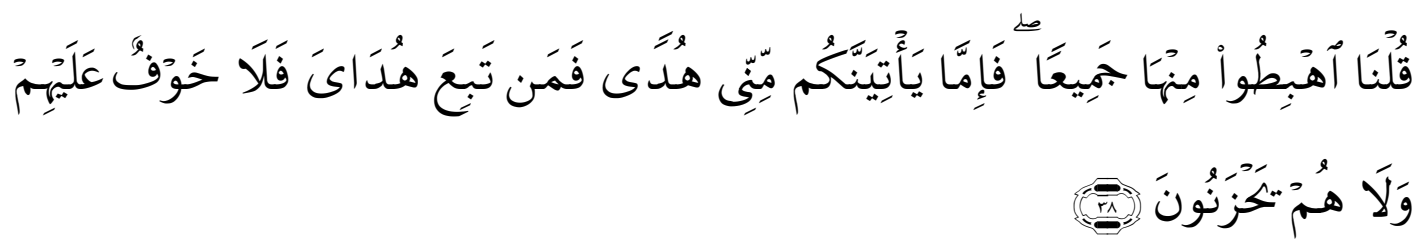

Artinya: Kami berfirman: "Turunlah kamu semuanya dari surga itu! kemudian jika datang petunjuk-Ku kepadamu, Maka barang siapa yang mengikuti petunjuk-Ku, niscaya tidak ada kekhawatiran atas mereka, dan tidak (pula) mereka bersedih hati”. (Q.S. Al-Baqarah [2]: 38). ${ }^{34}$

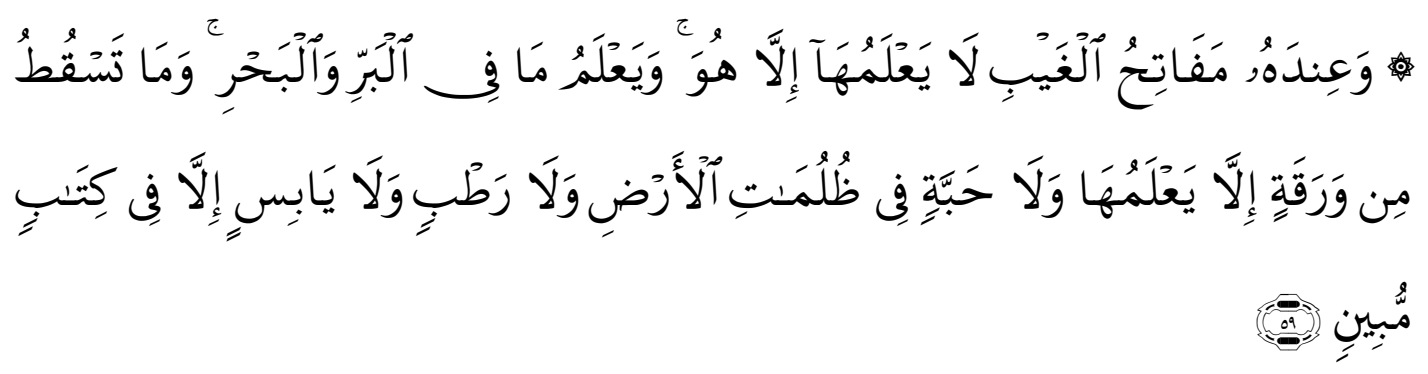

Artinya: "dan pada sisi Allah-lah kunci-kunci semua yang ghaib; tidak ada yang mengetahuinya kecuali Dia sendiri, dan Dia mengetahui apa yang di daratan dan di lautan, dan tiada sehelai daun pun yang gugur melainkan Dia mengetahuinya (pula), dan tidak jatuh sebutir biji-pun dalam kegelapan bumi, dan tidak sesuatu yang basah atau yang kering, melainkan tertulis dalam kitab yang nyata (Lauh Mahfudz)". (Q.S. AlAn'am [6]: 59). ${ }^{35}$

9. Kaidah Dhama'ir, Tadzkir dan Ta'nits

Dhamir (kata ganti) berfungsi untuk menghindari pemborosan kata, mempersingkat perkataan tanpa mengubah makna. ${ }^{36}$ Allah swt. berfirman dalam Q.S. Al-Ahzab ayat 35 yang berbunyi:

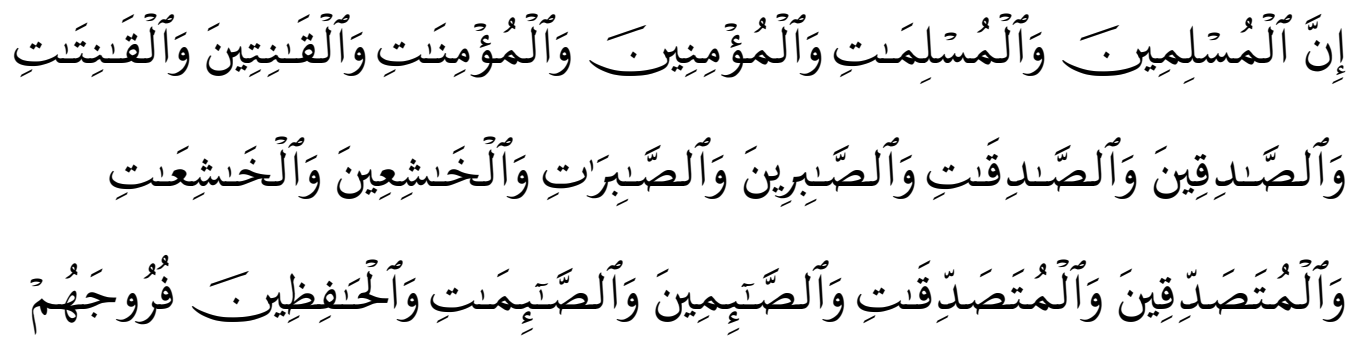

\footnotetext{
${ }^{34}$ Departemen Agama RI, Al-Hikmah; Al-Qur'an, 7.

${ }^{35}$ Departemen Agama RI, Al-Hikmah; Al-Qur'an, 134.

${ }^{36}$ Chirzin, Al-Qur'an, 220.
} 

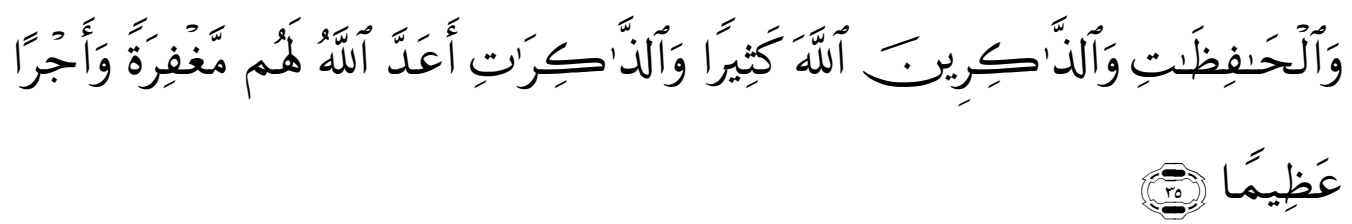

Artinya: "Sesungguhnya laki-laki dan perempuan yang muslim, laki-laki dan perempuan yang mukmin, laki-laki dan perempuan yang tetap dalam ketaatannya, laki-laki dan perempuan yang benar, laki-laki dan perempuan yang sabar, laki-laki dan perempuan yang khusyuk, laki-laki dan perempuan yang bersedekah, laki-laki dan perempuan yang berpuasa, laki-laki dan perempuan yang memelihara kehormatannya, laki-laki dan perempuan yang banyak menyebut (nama) Allah, Allah telah menyediakan untuk mereka ampunan dan pahala yang besar". (Q.S. AlAhzab [33]: 35). ${ }^{37}$

Selain itu, dalam gramatika bahasa Arab dibedakan antara kata penyebutan untuk perempuan (mu'annats) dan kata penyebutan untuk laki-laki (mudzakkar). Hal ini berfungsi untuk mengidentifikasi khitab atau yang dituju oleh sebuah pernyataan. $^{38}$

10. Kaidah Syarat dan Hadzf Jawabusy-Syarth

Dalam ilmu nahwu, adawatusy-yarth (kata-kata syarat) terbagi dalam dua bagian, yaitu kata syarat yang menjazamkan fi'il: in, idzma, man, kaifama, haitsuma, aina, ayyana, ayyun dan mahma, dan kata syarat yang tidak menjazamkan: lau, laula, idza, kullama dan lamma. Kalimat yang didahului dengan kata syarat dikenal dengan nama jumlah syarthiyyah. ${ }^{39}$ Contohnya dapat dilihat pada firman Allah dalam Q.S. Al-Baqarah ayat 284 yang berbunyi:

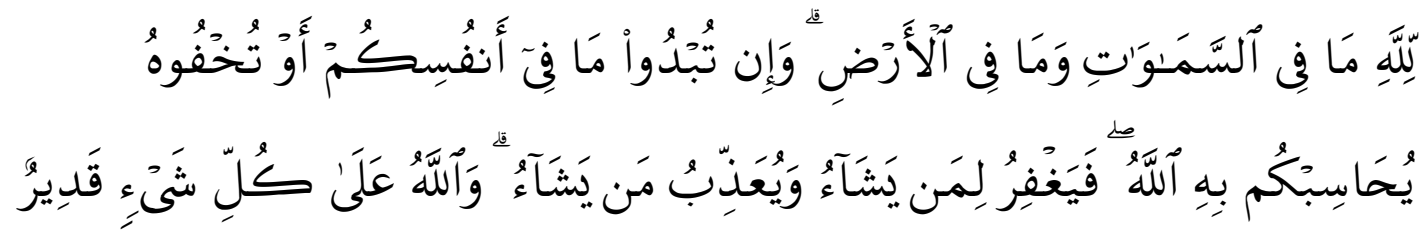

Artinya: "Kepunyaan Allah-lah segala apa yang ada di langit dan apa yang ada di bumi. dan jika kamu melahirkan apa yang ada di dalam hatimu atau kamu menyembunyikan, niscaya Allah akan membuat perhitungan dengan kamu tentang perbuatanmu itu. Maka Allah mengampuni siapa yang dikehandaki-Nya dan menyiksa siapa yang dikehendaki-Nya; dan Allah Maha Kuasa atas segala sesuatu". (Q.S. Al-Baqarah [2]: 284). ${ }^{40}$

\footnotetext{
${ }^{37}$ Departemen Agama RI, Al-Hikmah; Al-Qur'an, 422.

${ }^{38}$ Chirzin, Al-Qur'an, 222.

${ }^{39}$ Chirzin, Al-Qur'an, 226.

${ }^{40}$ Departemen Agama RI, Al-Hikmah; Al-Qur'an, 49.
} 
Sementara itu, apabila jawabusy-syarth dari jumlah syartiyyah dibuang, maka itu menunjukkan pentingnya masalah yang dibicarakan. Jika ia membicarakan masalah siksa, maka itu menunjukkan dahsyatnya siksaan tersebut, ${ }^{41}$ sebagaimana firman Allah dalam Q.S. As-Sajadah ayat 12 yang berbunyi:

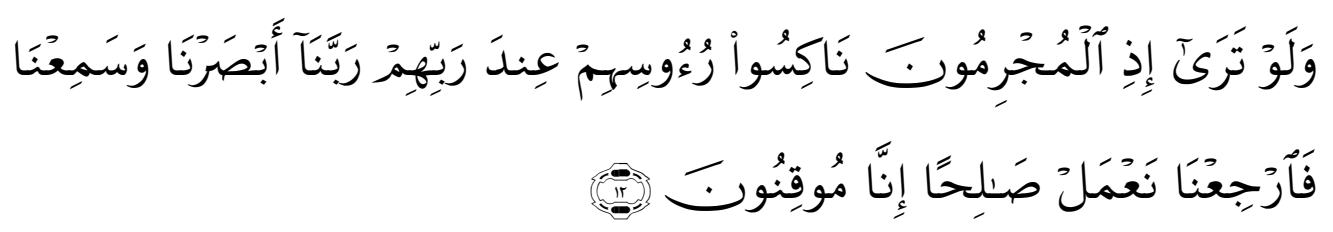

Artinya: "Dan, jika sekiranya kamu melihat mereka ketika orang-orang yang berdosa itu menundukkan kepalanya di hadapan Tuhannya, (mereka berkata): "Ya Tuhan Kami, Kami telah melihat dan mendengar, Maka kembalikanlah Kami (ke dunia), Kami akan mengerjakan amal saleh, Sesungguhnya Kami adalah orang-orang yang yakin”. (Q.S. As-Sajadah $[32]: 12)^{42}$

11. Kaidah Hadzful Maf'ul

Hadzful maf'ul merupakan peniadaan atau pembuangan objek dalam kalimat. Apabila suatu kata kerja dihubungkan dengan suatu objek tertentu, pengertiannya menjadi terbatas hanya pada kata yang berkaitan. Akan tetapi jika objek kata kerja itu ditinggalkan, maka kata tersebut memiliki pengertian yang lebih luas dan umum. ${ }^{43}$ Contohnya terdapat pada firman Allah Q.S. Al-'Alaq ayat 1-3 yang berbunyi:

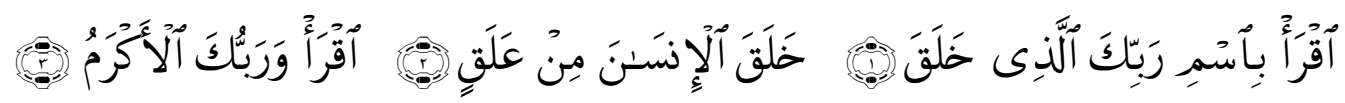

Artinya: "Bacalah dengan (menyebut) nama Tuhanmu yang Menciptakan, Dia telah menciptakan manusia dari segumpal darah. Bacalah, dan Tuhanmulah yang Maha pemurah”. (Q.S. Al-`Alaq [96]: 1-3). ${ }^{44}$

12. Kaidah Redaksi Kalimat Umum dengan Sebab Khusus

Apabila ditemukan ayat-ayat Al-Qur'an yang memiliki hubungan dengan suatu hukum dan konteks yang dibicarakan bersifat khusus terhadap kasus tertentu, sedangkan teks ayatnya bersifat umum, maka ketentuan seperti itu tidak hanya terfokus pada kasus tersebut, tetapi berlaku secara umum pada kasus-kasus yang memiliki persamaan dengan kasus khusus tersebut. ${ }^{45}$ Sebagaimana firman Allah dalam Q.S. An-Nur ayat 6 yang berbunyi:

\footnotetext{
${ }^{41}$ Chirzin, Al-Qur'an, 229.

${ }^{42}$ Departemen Agama RI, Al-Hikmah; Al-Qur'an, 416.

${ }^{43}$ Chirzin, Al-Qur'an, 233.

${ }^{44}$ Departemen Agama RI, Al-Hikmah; Al-Qur'an, 597.

${ }^{45}$ Chirzin, Al-Qur'an, 239.
} 


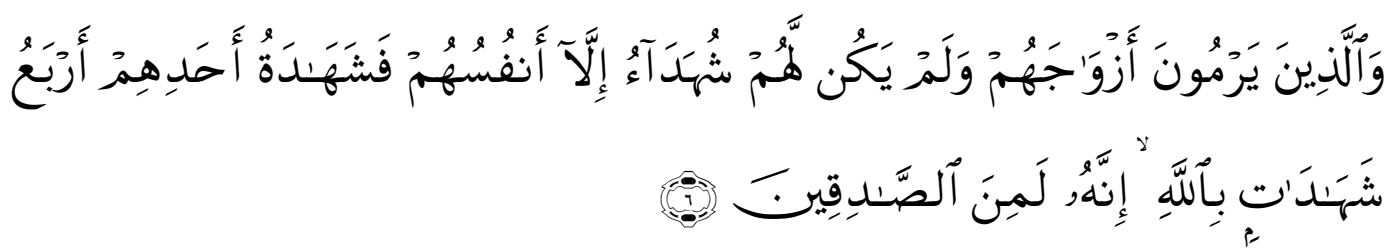

Artinya: "Dan orang-orang yang menuduh isterinya (berzina), Padahal mereka tidak ada mempunyai saksi-saksi selain diri mereka sendiri, Maka persaksian orang itu ialah empat kali bersumpah dengan nama Allah, Sesungguhnya Dia adalah Termasuk orang-orang yang benar”. (Q.S. AnNur [24]: 6). ${ }^{46}$

Dari penjelasan di atas, tentang kategorisasi kaidah penafsiran yang bisa dijadikan pedoman dalam menafsirkan Al-Qur'an di era disrupsi menurut pandangan Abd ar-Rahman ibn Nasir al-Sa'adi dalam kitabnya Al-Qawaid Al-Hisan li Tafsir AlQur'an yang dikutip oleh Abd. Rahman Dahlan dan Muhammad Chirzin pada dasarnya adalah sama meskipun ada yang merumuskannya secara luas dan ada pula yang merumuskannya secara singkat. Sehingga, dalam hemat penulis pendapat keduanya secara bersamaan menjadi hal fundamental bagi seorang yang hendak menafsirkan AlQur'an di era disrupsi ini.

Selain menerapkan kaidah-kaidah tersebut, apabila seseorang hendak menafsirkan Al-Qur'an di era disrupsi saat ini, maka harus memiliki syarat-syarat pokok sebagai mufassir, yaitu: Pertama, memiliki aqidah yang benar. Kedua, bersih dari hawa nafsu. Ketiga, memiliki niat baik dan tujuan yang benar. Keempat, taat dan mengamalkan ilmunya. Kelima, berpegang teguh pada sunnah. Keenam, mengerahkan tenaga untuk belajar atau membekali diri dengan ilmu. ${ }^{47}$

Sementara itu, As-Suyuthi sebagaimana yang dikutip oleh Asy-Syirbashi mengemukakan bahwa seseorang yang hendak menafsirkan Al-Qur'an harus memiliki ilmu-ilmu, yaitu: Pertama, Ilmu bahasa diperlukan untuk mengetahui arti kosa-kata (perbendaharaan kata) dan maknanya berdasarkan letak setiap kata dalam rangkaian kalimat. Kedua, Ilmu nahwu diperlukan untuk mengetahui bahwa suatu kata dapat berganti maknanya dan memiliki arti lain dikarenakan adanya perubahan i'rab. Ketiga, Tashrif (Ilmu sharaf) digunakan untuk mengetahui bentuk kata yang tidak berubah dan yang berubah (mu'rab dan mabni) serta juga dapat merasakan paradigma (mizan) setiap kata dan sifatnya. Keempat, Ilmu etimologi diperlukan untuk mengetahui dasar pembentukan asal-kata yang menyebabkan lahirnya kata-kata serumpun tetapi memiliki makna yang berbeda. Kelima, Ilmu retorika diperlukan untuk memahami ayat-ayat yang sukar. Keenam, Ilmu membaca diperlukan untuk menjabarkan bagaimana ayat-ayat Al-Qur'an harus diucapkan. Ketujuh, Ilmu ushuluddin diperlukan untuk mencari dalil-dalil pembuktian dari Al-Qur'an tentang berbagai masalah yang mustahil, wajib dan ja'iz. Kedelapan, Ilmu ushul fiqh diperlukan sebagai pembuktian

\footnotetext{
${ }^{46}$ Departemen Agama RI, Al-Hikmah; Al-Qur'an, 350.

${ }^{47}$ Imam Masrur, "Telaah Kritis Syarat Mufassir Abad Ke-21", dalam QOF Jurnal IAIN Kediri 2, no 2 (2018): 187-201
} 
tentang hukum agama Islam. Kesembilan,Ilmu asbabun nuzul diperlukan untuk memahami dengan jelas maskud setiap ayat dalam Al-Qur'an. Kesepuluh, Ilmu nasikh dan mansukh diperlukan untuk mengetahui ayat-ayat yang muhkamat dan yang mansukh. Kesebelas, Ilmu hadis diperlukan untuk memberikan keterangan tentang ayat yang mujmal dan mubham. Keduabelas, Ilmu mauhabah sebagai pengetahuan yang dianugerahkan secara langsung oleh Allah swt. kepada orang yang mengamalkan ilmunya. $^{48}$

Jadi, menurut hemat penulis dapat dipahami bahwa ketika seseorang hendak menafsirkan Al-Qur'an haruslah memenuhi syarat-syarat sebagai penafsir, memiliki ilmu-ilmu untuk menafsirkan dan memahami serta menggunakan kaidah-kaidah dalam menafsirkan Al-Qur'an. Hal ini dikarenakan jika seseorang menafsirkan Al-Qur'an tanpa memperhatikan dan memiliki komponen-komponen tersebut, maka akan terjadilah kekeliruan dan kesalahan dalam menafsirkan Al-Qur'an yang dapat berdampak buruk bagi kemaslahatan umat.

\section{Urgensi Kaidah Penafsiran Al-Qur'an di Era Disrupsi}

Pada era disrupsi ini, generasi muda atau yang dikenal dengan istilah milenial lebih unggul dibanding generasi sebelumnya dalam hal kecerdasan intelektual dan kekuatan fisik, namun dalam kecerdasan emosional dan kecerdasan spiritualnya mengalami banyak kendala. Hal ini dikarenakan pada era disrupsi perubahanperubahan terjadi dari dunia nyata ke dunia maya dalam tempo yang sangat cepat. AlQur'an sebagai salihun likulli zaman wa makan melalui slogan teologis-dogmatis selalu memiliki relevansi dengan zaman dan tempat dari awal turun hingga era disrupsi yang terjadi saat ini.

Kaidah penafsiran dari awal perkembangannya sampai pada era disrupsi saat ini diibaratkan sebagai sebuah alat yang digunakan oleh penggunanya dalam memahami dan menafsirkan Al-Qur'an. Dengan alat ini, seorang mufassir tidak hanya dapat terhindar dari berbagai kesalahan, tetapi juga dapat memperkaya pemahaman dan memperluas wawasan sehingga dapat memahami dan menoleransi pendapat-pendapat lain selama sejalan dengan kaidah-kaidah yang ada. ${ }^{49}$

Seorang mufassir dituntut untuk selalu mejaga dan memperhatikan segala konsekuensi makna yang terdapat di dalam ayat dan yang mengarah kepadanya, yaitu makna yang tidak dapat terjangkau oleh penyebutan lafadh ayat tetapi relevan dengannya. Karena menurut Abd. Rahman Dahlan, makna-makna ayat tersebut dapat digunakan sebagai dasar penetapan suatu hukum (al-istidlal). Selain itu, pedoman ini merupakan bagian penting untuk menafsirkan Al-Qur'an, karena disamping dapat merangsang ketajaman berpikir, upaya tersebut juga dapat mencerahkan pandangan, meluaskan wawasan dan meluruskan tujuan. ${ }^{50}$

\footnotetext{
${ }^{48}$ Ahmad Asy-Syirbashi, Sejarah Tafsir Al-Qur'an (Jakarta: Pustaka Firdaus, 1985), 25-29.

${ }^{49}$ Shihab, Kaidah Tafsir, 15.

${ }^{50}$ Abd. Rahman Dahlan, Kaidah-Kaidah Tafsir(Jakarta: Amzah, 2010), 5.
} 
Kaidah penafsiran di era disrupsi ini dapat membantu seseorang atau generasi milenial untuk mengungkap makna tersurat atau bahkan tersirat di dalam Al-Qur'an, sehingga dapat mengetahui apa yang sekiranya masih samar dan belum jelas. Adapun letak penting menggunakan kaidah penafsiran Al-Qur'an di era disrupsi ini, yaitu: Pertama, agar tidak terjadi penyimpangan dalam menafsirkan Al-Qur'an. ${ }^{51}$ Misalnya, ayat-ayat jihad (Q.S. Al-Hajj: 78, Q.S. At-Taubah: 41, dan Q.S. Al-Anfal: 72) dan ayat-ayat perang (Q.S. At-Taubah: 5 dan 36, Q.S. Al-Hajj: 39-41, Q.S. Al-Baqarah: 190) dalam Al-Qur'an yang sering kali disalahpahami dan dijadikan dalil bagi tindakan-tindakan radikalisme. ${ }^{52}$

Kedua, agar tidak memberikan arti etimologis suatu lafadh Al-Qur'an dengan arti lain yang tidak sesuai, baik dalam arti hakiki maupun arti majazi. ${ }^{53}$ Misalnya, penafsiran Q.S. Al-Ahzab ayat 33 sebagai fenomena "cocokologi" ayat Al-Qur' an saat wabah Covid-19 oleh para generasi milenial Indonesia. Dalam hemat penulis, tindakan "cocokologi" ini adalah bentuk tidak adanya pemahaman terhadap kaidah dalam menafsirkan Al-Qur'an dan hal ini sangat menciderai akidah Islam. Jika dilihat berdasarkan asbabun nuzul Q.S. Al-Ahzab ayat 33 secara implisit dikhususkan untuk istri Nabi Muhammad saw. karena kondisi masyarakat yang ada ketika masa itu masih sangat dibatasi ruang gerak perempuan ${ }^{54}$ dan dalam kaitannya dengan era disrupsi saat ini adalah untuk mencegah perempuan-perempuan Indonesia untuk berperilaku liar tanpa kendali agama.

Berpedoman kepada problem-problem di atas, maka faktor-faktor yang mengakibatkan kekeliruan dalam menafsirkan Al-Qur'an di era disrupsi, yaitu: Pertama, subjektivitas mufassir. Kedua, kekeliruan dalam menerapkan metode atau kaidah. Ketiga, kedangkalan pengetahuan tentang ilmu-ilmu alat. Keempat, minimnya pengetahuan tentang materi Al-Qur'an. Kelima, kurang memperhatikan konteks, seperti; asbabun nuzul, munasabah dan kondisi sosial masyarakat. Keenam, tidak memperhatikan siapa pembicara dan terhadap siapa pembicaraan ditujukan. ${ }^{55}$

Pada akhirnya dengan memahami dan menerapkan kaidah-kaidah penafsiran akan dapat menghindari kekeliruan dan kesalahan dalam menafsirkan Al-Qur'an. Sehingga berdasarkan pemaparan dalam tulisan ini dapat dipahami bahwa urgensi kaidah penafsiran di era disrupsi dengan generasi milenial sebagai tokoh utamanya sangatlah vital untuk menghindari kekeliruan dan kesalahan bahkan menjadi sebuah keniscayaan dalam menafsirkan atau memahami makna Al-Qur'an secara utuh.

\footnotetext{
${ }^{51}$ Ahmad Izzan, Metodologi Ilmu Tafsir, (Bandung: Tafakur, 2011), 121.

${ }^{52}$ Dede Rodin, "Islam dan Radikalisme: Telaah atas Ayat-ayat "Kekerasan" dalam al-Qur'an", dalam $A D D I N 10$, no. 1 (2016): 29-60.

${ }^{53}$ Izzan, Metodologi Ilmu, 121.

${ }^{54}$ Naili Fauziah Lutfiani, "Hak-Hak Perempuan dalam Surat Al-Ahzab Ayat 33: Sebuah Pendekatan Hermeneutik", dalam el-Tarbawi; Jurnal Pendidikan Islam 10, no. 2 (2017): 63-83.

${ }^{55}$ Ahmad Izzan, Studi Kaidah Tafsir Al-Qur'an (Bandung: Humaniora, 2009), 3.
} 


\section{Penutup}

Kaidah penafsiran Al-Qur'an di era disrupsi merupakan ketetapan-ketetapan yang membantu seorang penafsir atau mufassir untuk menarik makna/pesan-pesan AlQur'an dan menjelaskan apa yang musykil dari kandungan ayat-ayatnya dalam kaitannya dengan perubahan yang semakin tidak terduga. Ketika seseorang hendak menafsirkan Al-Qur'an haruslah memenuhi syarat-syarat sebagai penafsir, memiliki ilmu-ilmu untuk menafsirkan Al-Qur' an. Kaidah-kaidah dalam menfasirkan Al-Qur'an yang bisa dijadikan pedoman di era disrupsi ini dapat merujuk kepada pandangan Abd ar-Rahman ibn Nasir al-Sa'adi dalam kitabnya Al-Qawaid Al-Hisan li Tafsir Al-Qur'an sebagaimana yang dikutip oleh Abd. Rahman Dahlan bahwa ada lima kaidah penafsiran Al-Qur'an. Sedangkan, Muhammad Chirzin dalam bukunya mengemukakan dua belas kaidah penafsiran Al-Qur'an yang bisa dijadikan pedoman di era disrupsi.

Sementara itu, urgensi kaidah penafsiran Al-Qur'an di era disrupsi memainkan peran vital karena, yaitu; pertama, dapat membantu seseorang penafsir dalam mengungkap makna yang tersurat atau bahkan tersirat di dalam Al-Qur'an, sehingga dapat mengantarnya mengungkap apa yang sekiranya masih samar dan belum jelas. Kedua, agar tidak memberikan arti etimologis suatu lafadh Al-Qur'an dengan arti lain yang tidak sesuai, baik dalam arti hakiki maupun arti majazi.

\section{DAFTAR PUSTAKA}

Al-Qattan, Manna' Khalil, Studi Ilmu-Ilmu Al-Qur'an, Bogor: Pustaka Lintera Antar Nusa, 1994.

Ash Shiddieqy, Muhammad Hasbi, Sejarah dan Pengantar Ilmu Al-Qur'an/Tafsir, Jakarta: Bulan Bintang, 1992.

As-Shalih, Subhi, Membahas Ilmu-Ilmu Al-Qur'an, Jakarta: Pustaka Firdaus, 2011. Asy-Syirbashi, Ahmad, Sejarah Tafsir Al-Qur'an, Jakarta: Pustaka Firdaus, 1985. Bashori, Khoiruddin, "Pendidikan Politik di Era Disrupsi", dalam Sukma: Jurnal Pendidikan 2, No. 2 (2018).

Chirzin, Muhammad, Al-Qur'an dan Ulumul Quran, Jakarta: Dana Bhakti Prima Yasa, 1998.

Dahlan, Abd. Rahman, Kaidah-Kaidah Penafsiran Al-Qur'an, Bandung: Mizan, 1997. , Kaidah-Kaidah Tafsir, Jakarta: Amzah, 2010.

Departemen Agama RI, Al-Hikmah; Al-Qur'an dan Terjemahannya, Bandung: Diponegoro, 2008.

Hermawan, Bayu, "Netizen Dihebohkan dengan 'Berubahnya' Tafsir Al Maidah Ayat 51”, (Online), diakses dari https://www.republika.co.id, pada tanggal 20 Desember 2019 pukul 09.00 WIB.

Izzan, Ahmad, Metodologi Ilmu Tafsir, Bandung: Tafakur, 2011. , Studi Kaidah Tafsir Al-Qur'an, Bandung: Humaniora, 2009. 
Lutfiani, Naili Fauziah, "Hak-Hak Perempuan dalam Surat Al-Ahzab Ayat 33: Sebuah Pendekatan Hermeneutik", dalam el-Tarbawi; Jurnal Pendidikan Islam 10, no. 2 (2017).

Masrur, Imam, “Telaah Kritis Syarat Mufassir Abad Ke-21” dalam QOF Jurnal IAIN Kediri 2, no. 2 (2018).

Paman, Supiana-M., Ulumul Qur'an, Bandung: Pustaka Islamika, 2002.

Rodin, Dede, "Islam dan Radikalisme: Telaah atas Ayat-ayat "Kekerasan" dalam alQur'an", dalam ADDIN 10, no. 1 (2016).

Shihab, M. Quraish, Kaidah Tafsir, Syarat, Ketentuan dan Aturan yang Patut Anda Ketahui dalam Memahami Ayat-Ayat Al-Qur'an, Tangerang: Lentera Hati, 2013.

Thabathaba'i, Allamah M.H., Mengungkap Rahasia Al-Qur'an, Bandung: Mizan, 1994.

Tim Mahasiswa Pasca Sarjana PAI UIN Sunan Kalijaga A2 '17, Studi Al-Qur'an:

Teori dan Aplikasinya dalam Penafsiran Ayat Pendidikan, Yogyakarta: Diandra Kreatif, 2018.

Winarno, Hery H, 'MUI: Musnahkan Al-Qur' an Miracle The Reference yang Salah Tafsir", (Online), diakses dari https://www.merdeka.com, pada tanggal 20 Desember 2019 pukul 08.56 WIB. 